\title{
Teatro musical y perspectiva de género: la obra sicalíptica de Vicente Lleó durante su etapa en el Teatro Eslava de Madrid (1907- 1912)
}

\author{
Theater musical and gender perspective: the sicaliptic \\ work of Vicente Lleo during his stage at the Eslava \\ Theater of Madrid (1907-1912)
}

\section{Teatro musical e perspectiva de genero: o trabalho sicalippico de Vicente Lleó durante sua fase no Teatro da Eslava de Madrid (1907-1912)}

\author{
iD José Salvador Blasco Magraner ${ }^{1}$ \\ Universidad de Valencia, Valencia, España. \\ iD (9) Pablo Marín-Liébana² \\ Universidad de Valencia, Valencia, España. \\ iD Francisco Carlos Bueno Camejo 3 \\ Universidad de Valencia, Valencia, España.
}

Resumen: A principios del siglo XX surgió un nuevo modelo de teatro bufo denominado género sicalíptico caracterizado por sus altas dosis de frivolidad y erotismo que hizo furor en la escena madrileña. Vicente Lleó Balbastre (1870-1922) fue el máximo exponente del género en el

\footnotetext{
1 Doctor en Sociología y Ciencias Humanas y Licenciado en Historia y Ciencias de la Música por la Universidad Católica de Valencia. Recibió el Premio Extraordinario de Doctorado por su tesis titulada "Vicente Peydró Díez: vida y obra". Es también Licenciado en Dirección de orquesta por la prestigiosa Associated Board of the Royal Schools of Music de Londres y Diplomado en Didáctica de la lengua inglesa por la Universitat de València. Es también editor de la editorial "Latina" en la colección de Cuadernos de Bellas Artes. En la actualidad es Profesor Ayudante Doctor en el Departamento de Didáctica de la Expresión Musical, Plástica y Corporal en la Facultad de Magisterio de la Universitat de València.

2 Pablo Marín-Liébana: Personal investigador del Departamento de Didáctica de la Expresión Musical, Plástica y Corporal en la Facultad de Magisterio de la Universitat de València. Es Diplomado en Educación Social, Grado en Maestro en Educación Primaria y Máster en Didácticas Específicas por la Universitat de València, Licenciado en Historia y Ciencias de la Música por la Universidad de la Rioja, Máster en Memoria y Crítica de La Educación por la Universidad Nacional de Educación a Distancia y Grado Profesional en Guitarra por el Taller de Música Jove de Valencia. Su actividad investigadora se centra en el desarrollo de recursos audiovisuales para favorecer los procesos de escucha, el análisis de libros de texto y la didáctica musical crítica

3 Doctor en Filosofía y Ciencias de la Educación y Licenciado en Geografía e Historia por la Universitat de València. Asimismo, es Licenciado en Musicología por la Universidad de La Rioja y Catedrático en Geografía e Historia. Es editor de la editorial “Latina” en la colección de Cuadernos de Bellas Artes. En la actualidad es Profesor Titular del Departamento de Historia del Arte en la Facultad de Geografía e Historia de la Universitat de València.
} 
teatro musical. Bajo su dirección, como empresario y compositor, el Teatro Eslava se convirtió en el templo de la sicalipsis. En este artículo se estudia el nacimiento y eclosión del género, se recopilan todas las obras sicalípticas de Vicente Lleó en la época dorada de la sicalipsis en el teatro musical y se analizan las principales características de su estilo compositivo.

Palabras clave: Género sicalíptico, Mujer, Vicente Lleó, Género chico, Teatro Eslava, Opereta.

Abstract: At the beginning of the twentieth century, a new model of the bufo theater called the sicaliptic genre was characterized by its high doses of frivolity and eroticism that made a furor in the Madrid scene. Vicente Lleó Balbastre (1870-1922) was the greatest exponent of the genre in musical theater. Under his direction, as an entrepreneur and composer, the Eslava Theater became the temple of sicalipsis. In this article the birth and hatching of the genre are studied, all the sicaliptic works of Vicente Lleó are collected in the golden age of sicalipsis in the musical theater and the main characteristics of his compositional style are analyzed.

Keywords: Sicaliptic genre, Woman,Vicente Lleó, Género chico, Eslava Theater, Opereta.

Resumo: No início do século XX, um novo modelo de teatro bufo chamado gênero sicaliptico, caracterizado por suas altas doses de frivolidade e erotismo que assolavam a cena de Madrid. Vicente Lleó Balbastre (1870-1922) foi o maior expoente do gênero no teatro musical. Sob sua direção, como empresário e compositor, o Teatro Eslava tornou-se o templo da sicalipsis. Neste artigo, estuda-se o nascimento e a eclosão do gênero, todas as obras sicalípticas de Vicente Lleó são coletadas na era de ouro da sicalipsis no teatro musical e são analisadas as principais características de seu estilo composicional.

Palavras-chave: Gênero sicalíptico, Mulher, Vicente Lleó, Gênero pequeno, Teatro Eslava, Opereta. 
La obra sicalíptica de Vicente Lleó durante su etapa en el teatro eslava de Madrid (1907-1912) José Salvador Blasco Magraner • Pablo Marín-Liébana • Francisco Carlos Bueno Camejo

El teatro corto, siempre a imitación de los aristócratas de la ópera, ha favorecido una cultura sexual intensa entre los varones de las burguesías y las tiples, vice tiples, coristas, señoritas del conjunto y todo el personal femenino que se ha multiplicado con la expansión del género, un privilegio evidentemente envidiado por los que se veían excluidos por razones económicas

(Salaün, 2000, p. 102)

\section{Introducción}

A finales de la década de 1860, junto con la caída del régimen de Isabel II, la zarzuela pasó por un periodo de crisis debido al agotamiento de la fórmula que había creado la Sociedad Artística (ALIER, 2011). En este contexto apareció en Madrid el denominado teatro por horas de la mano del actor Antonio Riquelme, quien actuaba en el Teatro Recreo de la capital matritense. Riquelme implantó una modalidad teatral dividida por secciones breves que suplantaría a la habitual única función de cuatro o cinco horas de duración. De este modo el precio de los billetes se abarataba, puesto que el público podía obtener únicamente la entrada de una de las representaciones, al tiempo que el teatro no veía disminuidos sus ingresos. El invento resultó todo un éxito y poco a poco fue extendiéndose por todos los teatros de Madrid en los que se representaban juguetes cómicos, diálogos, monólogos y todas aquellas formas que no exigiesen más de tres o cuatro actores en el escenario (ÍNNIGUEZ-BARRENA, 1999). Poco a poco, el recién nacido teatro por horas, también denominado "género chico", pasó por una etapa de consolidación (1880-1890), -en la que autores destacados como Fernández Caballero, Asenjo Barbieri, Ruperto Chapí, Federico Chueca o Joaquín Valverde dejaron su impronta en el género-, y otra de apogeo (1890-1900), en la que proliferó toda una serie de obritas teatrales en un acto, "con denominaciones de todo tipo, desde sainete cómico a pasillo cómico-lírico, juguete lírico o cualquier otra combinación de nombres y adjetivos alusivos 
La obra sicalíptica de Vicente Lleó durante su etapa en el teatro eslava de Madrid (1907-1912) José Salvador Blasco Magraner • Pablo Marín-Liébana • Francisco Carlos Bueno Camejo

a lo que eran, en el fondo, zarzuelitas del género menor" (ALIER, 2011, p. 82). En los primeros años del siglo XX, con la pérdida de las últimas colonias en 1898 y la decadencia española, el género chico inició poco a poco su declive. Asimismo, la irrupción del erotismo escénico, de la canción de variedades y del cine contaminó al género chico desde dentro, creando una nueva modalidad teatral denominada "género sicalíptico", un tipo de género cuyas obras de naturaleza liviana eran francamente verdes. Los compositores del género chico del momento como Manuel Penella, Vicente Lleó, Rafael Calleja, Pablo Luna y Francisco Alonso optaron por la modalidad teatral sicalíptica más del gusto del público y todo ello trajo consigo la eclosión de este género (BARRERA, 1992).

\section{Contexto histórico}

A finales del siglo XIX y principios del XX parte de la sociedad española rechazaba los principios del concordatoy de la constitución impuestos por la Iglesia y el Estado. El papa León XIII escribió en 1882 la encíclica "Cum multa", en la que animaba a distintos grupos católicos españoles, como los carlistas y los integristas, a suavizar sus asperezas con los liberales moderados españoles y aceptar los principios de la Restauración. Este hecho facilitó la aparición de nuevas congregaciones religiosas. Asimismo, la vuelta a España de muchos religiosos debido a la pérdida de las colonias españolas $y$, sobre todo, al reconocimiento por parte de la burguesía de las actividades de las órdenes religiosas, como la caridad o la enseñanza, dio lugar a un aumento de la acción eclesiástica sobre la sociedad, al tiempo que una polarización política de la misma: "Las derechas se alinearon en el bando clerical y las izquierdas en el anticlerical. El propósito de Maura de elaborar un Convenio con la Santa Sede no llegó a concluirse y la Ley de Canalejas Ilamada del candado-resultó moderada para lo que se esperaba tras los furibundos ataques verbales típicos del momento" (PETSCHEN, 2002, p. 30). 
La obra sicalíptica de Vicente Lleó durante su etapa en el teatro eslava de Madrid (1907-1912) José Salvador Blasco Magraner • Pablo Marín-Liébana • Francisco Carlos Bueno Camejo

La sociedad española era patriarcal y conservadora y relegaba a la mujer a un rol subordinado y doméstico, limitando sus actividades fuera del vínculo familiar a la asistencia a los oficios religiosos y a la realización de unas pocas profesiones, como maestras y obreras. En el hogar la mujer debía encargarse del cuidado y de la educación de los hijos, así como de las tareas de coser, limpiar la casa y cuidar de la higiene personal de cada uno de los miembros de la familia (KIRKPATRICK, 2003). Los estereotipos femeninos retrataban a la mujer como un ser, dulce y encantador, pero, en cierta medida, ignorante e infantil. El propósito de la vida de las mujeres debía ser el de cuidar al esposo y aceptar su obediencia y fidelidad. El matrimonio, como sacramento, solo podía romperse con la muerte y la infidelidad conyugal, desde el punto de vista civil y penal, era mucho más estricta con la mujer que con el hombre (SÁNCHEZ, 2003).

La política educativa del siglo XIX y principios del XX cultivó una educación diferenciada para el varón y la mujer. La instrucción, en el caso de la mujer, quedó reducida al ámbito privado, siempre considerando la educación moral por encima de la instrucción propiamente dicha (BALLARIN, 1989). Efectivamente, desde finales de la centuria decimonónica hasta la Primera Guerra Mundial nos hallamos ante una etapa caracterizada por una notoria radicalización misógina, en la que la ciencia se convirtió en la instancia legitimadora de la verdad y fundamento para justificar las injusticias sociales (ARESTI, 2005). Las relaciones de género no variaron en España hasta los años veinte y treinta del siglo XX.

\section{Nacimiento y apogeo del género sicalíptico}

Las campañas moralizantes en la primera década del siglo XX de la Iglesia y del Estado no afectaron al significativo aumento del consumo teatral y a la creación de un nuevo erotismo escénico que a partir de 1900 afectó sobre todo al género chico y originó la aparición de un nuevo género denominado sicalipsis o género 
La obra sicalíptica de Vicente Lleó durante su etapa en el teatro eslava de Madrid (1907-1912) José Salvador Blasco Magraner • Pablo Marín-Liébana • Francisco Carlos Bueno Camejo

sicalíptico. El desarrollo de la sicalipsis fue consecuencia del ascenso social de las clases medias y su alianza con las populares que permitió la aparición y rentabilidad de nuevos espectáculos en detrimento de los antiguos. La plebeyez moral de este nuevo tipo de teatro no fue compartida ni aceptada por las clases altas. No obstante, el erotismo y lo "picante" no eran conceptos nuevos en la escenografía española. El estreno de El joven Telémaco en 1866 con texto de Eusebio Blasco y música de José Rogel supuso el inicio de un nuevo género bufo caracterizado por sus altas cotas de diversión y frivolidad que se oponía a la zarzuela grande y seria (VÍLLORA, 2007). Esta modalidad teatral cómica sería la predecesora del género sicalíptico.

La tradición teatral recogía la imagen de la mujer comúnmente aceptada por la sociedad de la época y en los escenarios de los teatros se representaban obras en las que el papel de la mujer quedaba fijado según la óptica masculina del momento. Sirva de ejemplo la opinión de Ozieblo quien afirma: "según el patriarcado lo único que puede y debe interesar a la mujer es cómo cazar marido, y las comedias derivadas de este tema. Hasta que el sexo deje de ser la principal preocupación del drama, esto necesariamente seguirá siendo así" (OZIEBLO, 2002, p. 18). Efectivamente, el sexo, y, más en concreto, la perversión sexual se convirtió en el principal reclamo del público que frecuentaba el teatro. En este sentido "la malicia sexual ya existía en el teatro, especialmente en las revistas, un género en el que lo erótico, lo sexual, el doble sentido del lenguaje, unido a las figurantas o bailarinas que en ellas actuaban constituían el aspecto más destacable de la representación" (BLASCO, 2014, p. 35).

No obstante, la primera vez que apareció el térmico sicalíptico fue en el diario madrileño "El Liberal" el 25 de abril de 1902 (MONTIJANO RUIZ, 2009). En dicho rotativo se hacía referencia a una nueva publicación altamente sicalíptica de grabados de mujeres desnudas titulada Las mujeres galantes. Muñoz Lorente, citando a Juan Corominas, coincide en que el vocablo sicalíptico surgió en 1902. Así consta en su Breve Diccionario Etimológico de la 
La obra sicalíptica de Vicente Lleó durante su etapa en el teatro eslava de Madrid (1907-1912) José Salvador Blasco Magraner • Pablo Marín-Liébana • Francisco Carlos Bueno Camejo

Lengua Castellana en el que se define la palabra sicalíptico como “Obsceno. 1902. Creado para anunciar una obra pornográfica, probablemente pensado en un cpt. del gr. Sykon (vulva) y aleiptikós, lo que sirve para frotar o excitar" (2008, p. 74). Por su parte, Enrique Rivas, cronista del rotativo "El Heraldo de Madrid" advertía de la rápida popularización del término sicalipsis en la escena teatral, así como los ardientes derroteros por los que iba a transcurrir el género sicalíptico. De acuerdo con Rivas (1906):

La Menegilda creada por Felipe Pérez ha fenecido á manos de la sicalipsis; ha sido preciso todo un género para matar un solo tipo; pero ya El arte de ser bonita ha suplantado á La Gran Vía. Nuestras más activas propagandistas de la reivindicación de la mujer quizás no hayan caído en la cuenta del enemigo que tienen en la sicalipsis (RIVAS, 1906, p. 4).

Junto con el nacimiento del término sicalíptico surgieron, en los primeros años del siglo XX, las primeras revistas eróticas en Madrid y Barcelona. Así, por ejemplo, en la capital de España se publicaba "La Pulga" (1901), mientras que en la Ciudad Condal empezaron a difundirse las revistas "Rojo y Verde", "Piripipiti" (1903) y "Chicharito" (1904). Sin embargo, la publicación erótica que más éxito obtuvo en la capital catalana fue "Sicalíptico" (1904). El perfil de estas revistas seguía siempre un mismo patrón: se trataba de publicaciones con imágenes de mujeres desnudas, sumisas y predispuestas a complacer los deseos sexuales del hombre. 
La obra sicalíptica de Vicente Lleó durante su etapa en el teatro eslava de Madrid (1907-1912) José Salvador Blasco Magraner • Pablo Marín-Liébana • Francisco Carlos Bueno Camejo

Figura 1: Portada del número 20 de la revista Sicalíptico correspondiente al 21 de mayo de 1904.

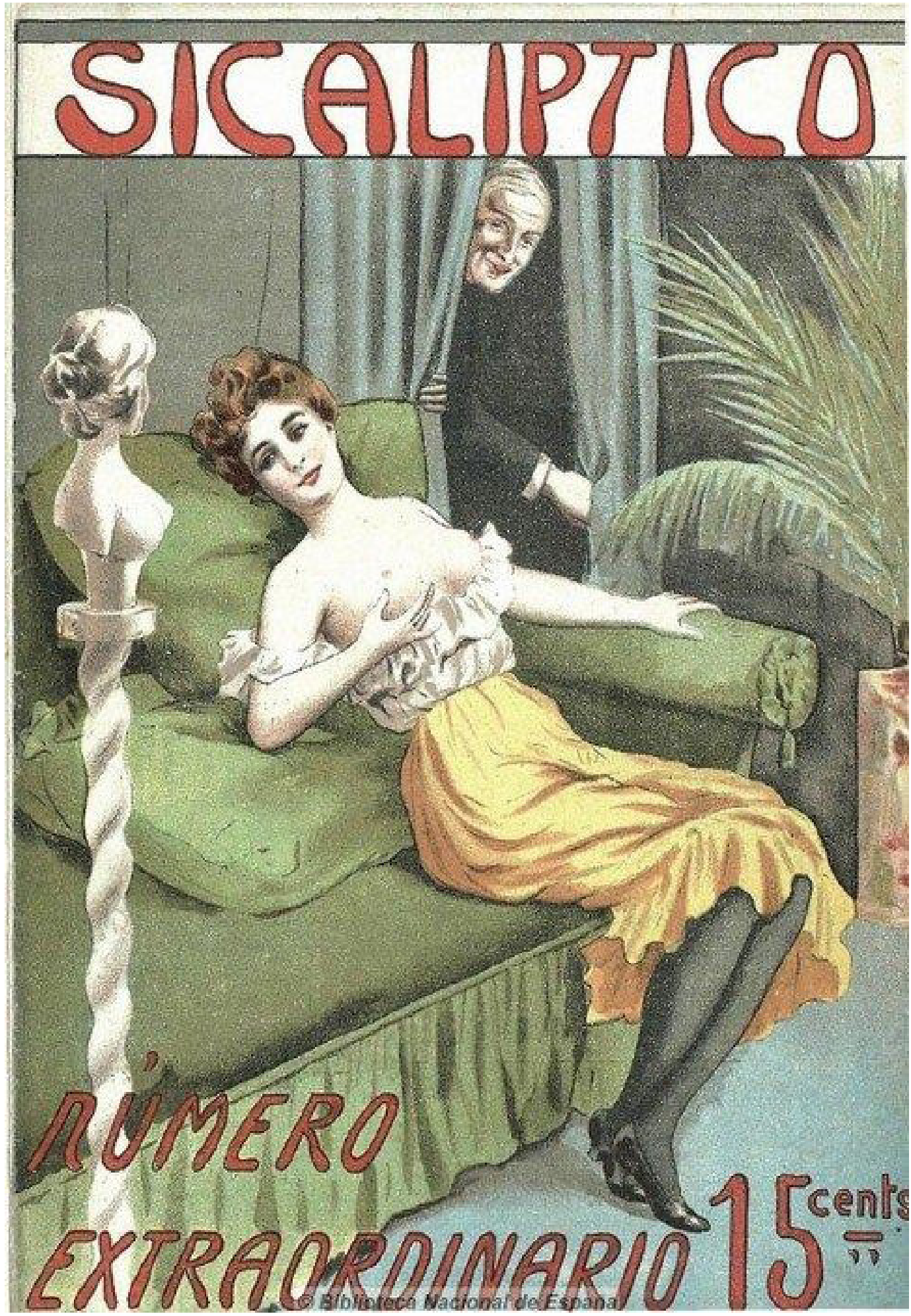

Fuente: Biblioteca Nacional de España. Madrid 
La obra sicalíptica de Vicente Lleó durante su etapa en el teatro eslava de Madrid (1907-1912) José Salvador Blasco Magraner • Pablo Marín-Liébana • Francisco Carlos Bueno Camejo

Ha menester agregar que a finales del siglo XIX aparecen en París las primeras películas eróticas. Las primeras son Le Couchier de la Mariée, dirigida por Albert Kirchner en 1896 y Après le bal de George Meliés de 1897 (VILCHES, 2017). Entre las primeras filmaciones de cine erótico en España destacan El confesor, El ministro y Consultorio de señoras, películas rodadas en la segunda década del siglo XX por los hermanos Ricardo y Ramón Baños y encargadas por el propio rey Alfonso XIII. Se trata de las tres únicas cintas que se conservan de la colección privada del monarca.

Por su parte, las obras precursoras del género sicalíptico en el teatro musical fueron El congreso feminista (1904), con libreto de Celso Lucio López y música de Joaquín Valverde hijo; El arte de ser bonita (1905), con texto de Antonio Paso Cano, Jiménez Prieto y López Laredo y música de Jerónimo Jiménez y Amadeo Vives, y, por último, La gatita blanca (1905), original de José Jackson Veyán y Jacinto Capella, con música de Amadeo Vives y Jerónimo Jiménez. Los escritores Carlos Arniches, Sinesio Delgado, López Silva, Ricardo de la Vega, Tomás Luceño y Ramos Carrión y los compositores Federico Chueca, Joaquín Valverde, Ruperto Chapí, $y$, sobre todo, Vicente Lleó fueron los principales autores de esta etapa inicial conocida como "revista blanca" (LABRADOR, 2005). 
La obra sicalíptica de Vicente Lleó durante su etapa en el teatro eslava de Madrid (1907-1912) José Salvador Blasco Magraner • Pablo Marín-Liébana • Francisco Carlos Bueno Camejo

Figura 2: La cantante del Eslava Julia Fons interpretando el papel de Luisa en la zarzuela La Gatita Blanca.

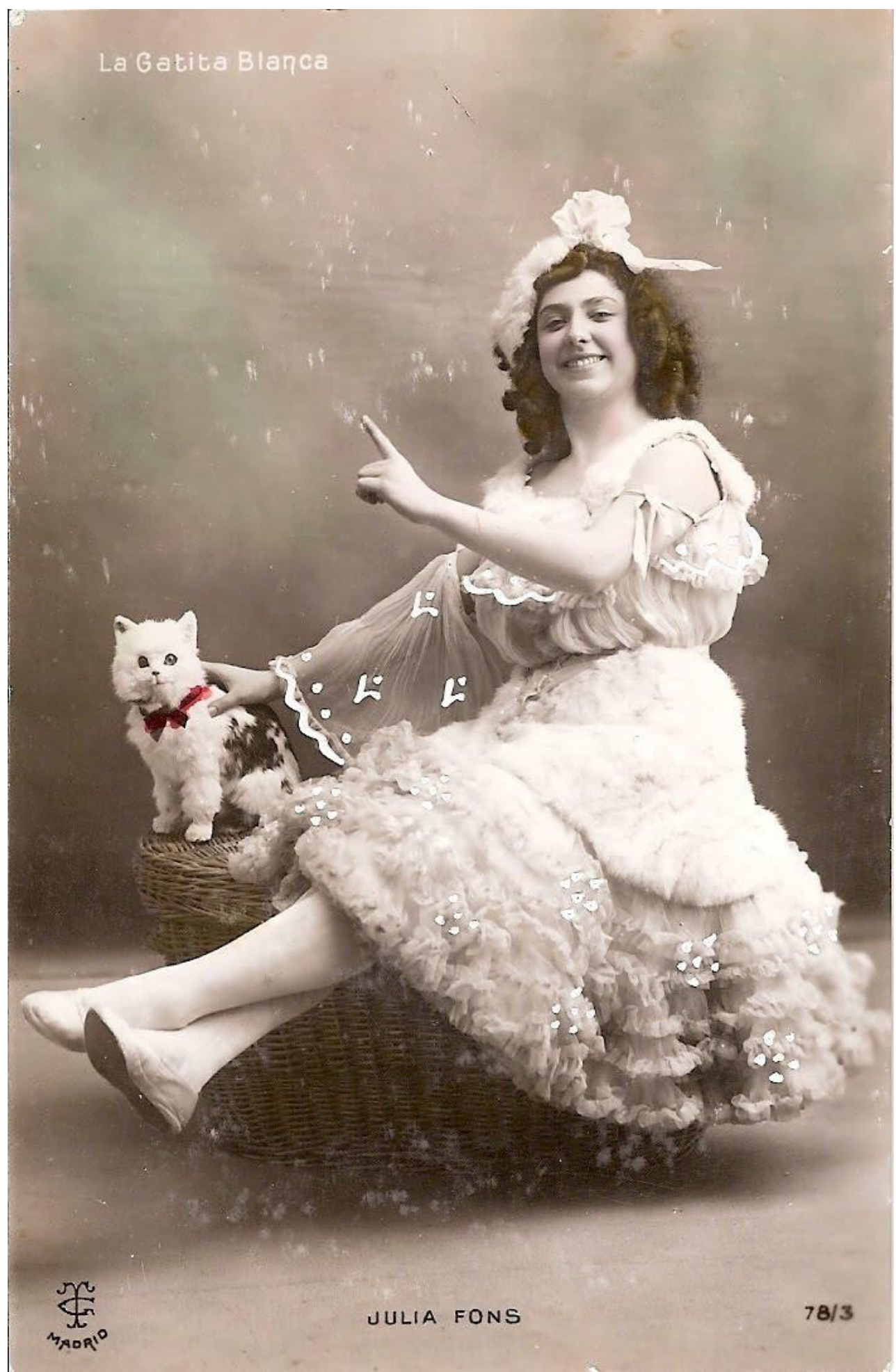

Fuente: Biblioteca Nacional de España. Madrid 
La obra sicalíptica de Vicente Lleó durante su etapa en el teatro eslava de Madrid (1907-1912) José Salvador Blasco Magraner • Pablo Marín-Liébana • Francisco Carlos Bueno Camejo

El estreno de El congreso feminista el 21 de marzo de 1904 en el Teatro Moderno de Madrid fue todo un acontecimiento. Gustó especialmente la actuación de la famosa pareja cómica Loreto Prado y Enrique Chicote, así como del resto de féminas de la compañía, destacando entre ellas Matilde Franco y Amalia Anchorena. Los críticos del momento predijeron que se celebrarían muchas sesiones de esta zarzuela allá donde fuere representada. Sin embargo, este vaticinio no se cumplió. Apenas un año más tarde, la obra que formaba parte de la cartelera del Teatro Principal de Ciudad de México fue suspendida por el juez de instrucción, advirtiendo a la compañía que se abstuviera de estrenar obras españolas hasta que no se resolviera el juicio que la empresa sostenía con el representante oficial de los autores ibéricos (LEAL, 2009).

Además de un amplio y variado ramillete de piezas frívolas, el nuevo género sicalíptico trajo consigo la proliferación de una nueva concurrencia teatral denominada "público sicalíptico", caracterizado por ser mayoritariamente masculino, de naturaleza trivial y ávido por saciar sus apetitos carnales más primarios. La presencia de la mujer en este tipo de espectáculos era muy reducida y se limitaba únicamente a las mujeres casadas. Asimismo, el nuevo género encumbró a la mujer, principal objeto de deseo, convirtiendo a las actrices en las verdaderas protagonistas de las funciones. Algunas de ellas llegaron a ser muy populares como Loreto Prado, Juanita Manso, Julia Fons o Carmen Andrés. Incluso un periódico de corte conservador como "El Heraldo de Madrid" publicó el 7 de noviembre de 1912 un artículo titulado "Las bellas de Eslava" en el que mostraba una fotografía con todas las tiples de la compañía que actuaba en el coliseo del Pasadizo de San Ginés, aseverando la belleza y el encanto que todas ellas desplegaban.

Vicente Lleó Balbastre fue el principal mantenedor del género sicalíptico y su máxima figura de referencia. Muchas de sus composiciones alcanzaron una popularidad notoria. La primera obra puramente sicalíptica de Vicente Lleó fue La taza de té, caricatura japonesa en un acto dividida en tres cuadros con libreto 
La obra sicalíptica de Vicente Lleó durante su etapa en el teatro eslava de Madrid (1907-1912) José Salvador Blasco Magraner • Pablo Marín-Liébana • Francisco Carlos Bueno Camejo

de Maximiliano Thous, Antonio Paso Cano y Joaquín Abati. La pieza se estrenó en el Teatro Cómico el 23 de marzo de 1906. En ella abundaban los chistes de color subido y los enredos y situaciones picantes que gustaron en extremo a la concurrencia. Destacaron las actrices Juanita Manso y Julia Fons en sus papeles de Azulina y Crisantema respectivamente. Los espléndidos decorados de Luis Muriel contribuyeron al éxito de la función. No obstante, la época dorada del género sicalíptico en el teatro musical aconteció entre los años 1907 y 1912, temporadas en las que Vicente Lleó, desde su posición como empresario y compositor del Teatro Eslava, llevó al género sicalíptico a su máxima expresión. De este periodo son los títulos Venus Kursaal (1906), La alegre trompetería (1907), La carne flaca (1908), La república del amor (1908), El método Gorritz (1909), La moral en peligro (1909) y, sobre todo, La corte de faraón (1910), la obra que más satisfizo al músico valenciano, alcanzando la increíble cifra de 772 representaciones y recorriendo con gran éxito los principales escenarios de España y América.

Tan solo tres obras de Vicente Lleó consiguieron romper los férreos moldes de la sicalipsis durante aquellos años: la zarzuela en un acto La copa encantada, con libreto de Jacinto Benavente, estrenada en el Teatro de La Zarzuela el 16 de marzo de 1907; el sainete en un acto Ninfas y sátiros, con texto de José López Silva y José Pellicer, inaugurado el 27 de marzo de 1909; y la opereta en tres actos El conde de Luxemburgo, con libreto de José Juan Cadenas y estrenada en el Eslava el 19 de octubre de 1910. La crítica más conservadora aprovechó la oportunidad para reprender duramente al género sicalíptico. Así, por ejemplo, a propósito del estreno de La copa encantada, el diario "El Heraldo de Madrid" del 17 de marzo de 1907 afirmaba que el buen arte salvaba los mayores compromisos, siendo innecesario ofender al auditorio subiendo al proscenio piezas pornográficas que exponían con brutalidad asuntos escabrosos con un lenguaje torpe y soez. Después de la primera representación de Ninfas y sátiros "El Heraldo de Madrid" del 28 de marzo de 1909 aseveraba que los libretistas Silva y Pellicer habían dado un golpe casi mortal al género sicalíptico. Por 
La obra sicalíptica de Vicente Lleó durante su etapa en el teatro eslava de Madrid (1907-1912) José Salvador Blasco Magraner • Pablo Marín-Liébana • Francisco Carlos Bueno Camejo

su parte, el periódico "El País" de ese mismo día era de la opinión que había nacido un nuevo género sensiblero sicalíptico. Por último, después de la inauguración de El conde de Luxemburgo el periódico "La Correspondencia de España" del 20 de octubre de 1910 afirmaba que la opereta rompía los moldes sicalípticos tan frecuentes en el coliseo del Pasadizo de San Ginés y que la pieza era tan original que vestía a las señoras en vez de desnudarlas.

\section{Tipología y rasgos generales de la obra sicalíptica de Vi- cente Lleó}

Vicente Lleó Balbastre es un autor que cuenta con una rica y variada producción lírica que supera los cien títulos, aunque muchas de sus obras fueron compuestas en colaboración con los compositores Rafael Calleja y Luis Foglietti (GALBIS, 2006). Asimismo, Lleó colaboró con menor asiduidad con autores de la talla de Amadeo Vives, Ángel Rubio Laínez, Joaquín Valverde, Luis Mariani, Enrique García Álvarez, Rodríguez Galea, Manuel Fernández Caballero, Reveriano Soutullo, Juan Vert Carbonell y Manuel Chalons.

En el periodo que nos ocupa, comprendido entre las temporadas teatrales de 1906-1907 hasta la de 1911-1912, un total de 35 obras de Vicente Lleó pertenecientes al género sicalíptico fueron representadas en los teatros matritenses Eslava (24), Cómico (6), Apolo (2), Teatro de la Zarzuela (2) y Gran Teatro (1). Entre ellas se encuentran 7 sainetes, 6 operetas, 5 zarzuelas, 3 entremeses, 2 fantasías, 2 juguetes cómico-líricos, 2 humoradas, 2 pasatiempos, 1 cuento cómico, 1 comedia lírica, 1 parodia, 1 disparate, 1 caricatura japonesa y 1 disgusto lírico. La mayoría de estas obras pertenecen al género chico y fueron estrenadas en el Teatro Eslava. Hay que tener en cuenta que Lleó tenía contrato como empresario y compositor en el coliseo del Pasadizo de San Ginés. 
La obra sicalíptica de Vicente Lleó durante su etapa en el teatro eslava de Madrid (1907-1912) José Salvador Blasco Magraner • Pablo Marín-Liébana • Francisco Carlos Bueno Camejo

Tabla 1. Obras del género sicalíptico estrenadas durante las temporadas de 1906-1907 y 1911-1912.

\begin{tabular}{|c|c|c|c|c|}
\hline OBRA & GÉNERO & ESTRENO & TEATRO & LIBRETO \\
\hline LA TAZA DE TÉ & $\begin{array}{l}\text { CARICATURA } \\
\text { JAPONESA }\end{array}$ & 23/03/1906 & CÓMICO & $\begin{array}{l}\text { M. THOUS, A. PASO CANO } \\
\text { Y J. ABATI }\end{array}$ \\
\hline LOS MOSQUETEROS & OPERETA & 06/09/1906 & $\begin{array}{l}\text { TEATRO DE LA } \\
\text { ZARZUELA }\end{array}$ & $\begin{array}{l}\text { J. ABATI, A. PASO CANO Y } \\
\text { E. SIERRA }\end{array}$ \\
\hline LA CASA DEL SOCORRO & ENTREMÉS & $27 / 10 / 1906$ & \begin{tabular}{|l|} 
TEATRO DE LA \\
ZARZUELA \\
\end{tabular} & $\begin{array}{l}\text { J. MOYRÓN Y M. FERNÁN- } \\
\text { DEZ PALOMERO }\end{array}$ \\
\hline $\begin{array}{l}\text { VENUS KURSAAL (RAFAEL } \\
\text { CALLEJA) }\end{array}$ & $\begin{array}{l}\text { FANTASÍA } \\
\text { CO-LIGERA }\end{array}$ & $31 / 10 / 1906$ & CÓMICO & $\begin{array}{l}\text { F. LIMENDOUX Y E. LÓPEZ } \\
\text { MARÍN }\end{array}$ \\
\hline LA GUEDEJA RUBIA & CUENTO CÓMICO & 07/12/1906 & CÓMICO & F. YRAIZOZ \\
\hline RUIDO DE CAMPANAS & COMEDIA LÍRICA & 18/01/1907 & ESLAVA & A. MARTÍNEZ VIERGOL \\
\hline $\begin{array}{l}\text { LA VIDA ALEGRE (FOGLIET- } \\
\mathrm{TI})\end{array}$ & HUMORADA & 05/04/1907 & CÓMICO & $\begin{array}{l}\text { J. CAPELLA Y M. FERNÁN- } \\
\text { DEZ }\end{array}$ \\
\hline LA HOSTERÍA DEL LAUREL & ZARZUELA & 26/04/1907 & CÓMICO & J. ABATI, A. PASO CANO \\
\hline APAGA Y VÁMONOS & PASATIEMPO & $31 / 05 / 1907$ & CÓMICO & $\begin{array}{l}\text { J. LÓPEZ SILVA Y J. JACK- } \\
\text { SON }\end{array}$ \\
\hline TODOS SOMOS UNO & SAINETE & 21/09/1907 & ESLAVA & J. BENAVENTE \\
\hline LA ALEGRE TROMPETERÍA & PASATIEMPO & 14/10/1907 & ESLAVA & A. PASO CANO \\
\hline TENORIO FEMINISTA & PARODIA & 31/10/1907 & ESLAVA & $\begin{array}{l}\text { A. PASO CANO Y I. VALDIV- } \\
\text { IA }\end{array}$ \\
\hline $\begin{array}{l}\text { EL POBRECITO PRÍNCIPE } \\
\text { (R. CALLEJA) }\end{array}$ & $\begin{array}{l}\text { DISPARATE SICALÍP- } \\
\text { TICO. }\end{array}$ & 28/12/1907 & ESLAVA & $\begin{array}{l}\text { J. DE BURGOS Y M. } \\
\text { FERNÁNDEZ PALOMERO }\end{array}$ \\
\hline $\begin{array}{l}\text { LA CORTE DE LOS CASA- } \\
\text { DOS (FOGLIETTI) }\end{array}$ & OPERETA & 08/02/1908 & ESLAVA & F. PÉREZ CAPO \\
\hline LA CARNE FLACA & HUMORADA & 21/03/1908 & ESLAVA & $\begin{array}{l}\text { J. JACKSON VEYÁN Y C. AR- } \\
\text { NICHES }\end{array}$ \\
\hline LA REGADERA & ENTREMÉS & 08/04/1908 & ESLAVA & $\begin{array}{l}\text { A. LARRUBIERA Y A. CASE- } \\
\text { RO }\end{array}$ \\
\hline MAYO FLORIDO & SAINETE & $22 / 05 / 1908$ & ESLAVA & J. ABATI, A. PASO CANO \\
\hline LA REPÚBLICA DEL AMOR & OPERETA & 26/09/1908 & ESLAVA & $\begin{array}{l}\text { A. PASO CANO, S. ARAGÓN } \\
\text { Y G. MARTÍNEZ SIERRA }\end{array}$ \\
\hline $\begin{array}{l}\text { LA GOLFA DEL MAN- } \\
\text { ZANARES (R. CALLEJA) }\end{array}$ & SAINETE & 08/10/1908 & GRAN TEATRO & L. DE LARA Y N. MARTÍNEZ \\
\hline LA BALSA DE ACEITE & SAINETE & 13/10/1908 & ESLAVA & S. DELGADO \\
\hline $\begin{array}{l}\text { SI LAS MUJERES MAN- } \\
\text { DASEN (FOGLIETTI) }\end{array}$ & FANTASÍA LÍRICA & 02/12/1908 & ESLAVA & $\begin{array}{l}\text { M. FERNÁNDEZ DE LA } \\
\text { FUENTE, L. PASCUAL FRU- } \\
\text { TOS } \\
\end{array}$ \\
\hline $\begin{array}{l}\text { LOS TRES MARIDOS BUR- } \\
\text { LADOS }\end{array}$ & SAINETE & 05/02/1909 & ESLAVA & J. DICENTA Y P. DE RÉPIDE \\
\hline $\begin{array}{l}\text { POR TODO LO ALTO } \\
\text { (FOGLIETTI) }\end{array}$ & ENTREMÉS & 22/05/1909 & ESLAVA & J. GONZÁLEZ PASTOT \\
\hline LOS HOMBRES ALEGRES & ZARZUELA & 01/06/1909 & ESLAVA & J. ABATI, A. PASO CANO \\
\hline
\end{tabular}


La obra sicalíptica de Vicente Lleó durante su etapa en el teatro eslava de Madrid (1907-1912) José Salvador Blasco Magraner • Pablo Marín-Liébana • Francisco Carlos Bueno Camejo

\begin{tabular}{|l|l|l|l|l|}
\hline EL MÉTODO GORRITZ & ZARZUELA & $18 / 06 / 1909$ & APOLO & $\begin{array}{l}\text { E. GARCÍA ÁLVAREZ Y C. } \\
\text { ARNICHES }\end{array}$ \\
\hline LA MORAL EN PELIGRO & ZARZUELA & $24 / 09 / 1909$ & ESLAVA & S. DELGADO \\
\hline LA CORTE DE FARAÓN & OPERETA BÍBLICA & $21 / 01 / 1910$ & ESLAVA & M. PALACIOS Y G. PERRÍN \\
\hline LA ALEGRE DOÑA JUANITA & OPERETA & $26 / 03 / 1910$ & ESLAVA & $\begin{array}{l}\text { E. CÓRDOBA Y M. } \\
\text { FERNÁNDEZ PALOMERO }\end{array}$ \\
\hline MEA CULPA & DISGUSTO LÍRICO & $21 / 05 / 1910$ & ESLAVA & J. ABATI, A. PASO CANO \\
\hline $\begin{array}{l}\text { COLGAR LOS HÁBITOS } \\
\text { (FOGLIETTI) }\end{array}$ & SAINETE & $02 / 06 / 1910$ & ESLAVA & A. DOMÍNGUEZ \\
\hline EL VALS DE LOS BESOS & $\begin{array}{l}\text { JUGUETE CÓMI- } \\
\text { CO-LÍRICO }\end{array}$ & $27 / 05 / 1911$ & ESLAVA & E. LÓPEZ MARÍN \\
\hline EL REVISOR & $\begin{array}{l}\text { JUGUETE CÓMI- } \\
\text { CO-LÍRICO }\end{array}$ & $13 / 06 / 1911$ & ESLAVA & E. MARIO Y R. BLASCO \\
\hline LA MUJER DIVORCIADA & OPERETA & $23 / 12 / 1911$ & ESLAVA & V. LEÓN Y J. CADENAS \\
\hline LOS BORREGOS & ZARZUELA & $10 / 05 / 1912$ & ESLAVA & A. MARTÍNEZ VIERGOL \\
\hline LA MAJA DE LOS CLAVELES & SAINETE & $24 / 05 / 1912$ & APOLO & $\begin{array}{l}\text { J. JOVER Y E. GONZÁLEZ } \\
\text { DEL CASTILLO }\end{array}$ \\
\hline
\end{tabular}

Fuente: Elaboración propia a partir de la documentación hallada en la Biblioteca Nacional de España. Madrid.

La irrupción del género sicalíptico en Madrid durante las temporadas 1906-1912 fue un hecho de gran trascendencia artística y social. Las obras de esta modalidad teatral copaban la mayor parte de la cartelera del Eslava y del Teatro Cómico, ambos coliseos especializados en el género chico. Asimismo, las piezas sicalípticas también se representaban en los proscenios de otros coliseos de la capital de España como el Apolo, el Teatro de la Zarzuela, el Teatro Romea y el Gran Teatro. La sociedad moderna demandaba espacios propios para la ocupación de su ocio, así como la contemplación de las obras teatrales y los intérpretes que ella quería. La burguesía, que acarreó los costes de las producciones, acabó imponiendo sus preferencias (OLIVA, 2000).

En general, las obras pertenecientes al género sicalíptico presentan las siguientes características:

- Se trata de obras de un único acto, propias del género chico, aunque no se circunscriban de forma única a este género

- A menudo los libretos son de escasa calidad literaria y de fácil comprensión 
La obra sicalíptica de Vicente Lleó durante su etapa en el teatro eslava de Madrid (1907-1912) José Salvador Blasco Magraner • Pablo Marín-Liébana • Francisco Carlos Bueno Camejo

- La temática sexual de naturaleza frívola es la principal motivación de la trama

- Utilización continua del doble sentido del lenguaje repleto de connotaciones sexuales y expresiones ordinarias

- La trama es tratada en clave de humor buscando obtener la risa facilona y el aplauso del espectador

- Crítica mordaz y burlesca al orden establecido, especialmente a las instituciones de la Iglesia y del Estado

- La mujer se convierte en el centro del espectáculo, verdadera protagonista y principal objeto de deseo

- Gran demanda de artistas y cantantes femeninas como cupletistas, tonadilleras, tiples, vicetiples, canzonetistas

- Frivolidad en la puesta en escena, donde se muestran las curvas y las pantorrillas de las actrices

- Algunas cantantes como Loreto Prado, Julia Fons o Juanita Manso se convirtieron en figuras artísticas de referencia del género

- Triunfo del cuplé como género escénico que ahora presenta un texto mucho más intencionado y directo

- El cuplé retrata sucesos intrascendentes y frívolos 
La obra sicalíptica de Vicente Lleó durante su etapa en el teatro eslava de Madrid (1907-1912) José Salvador Blasco Magraner • Pablo Marín-Liébana • Francisco Carlos Bueno Camejo

Figura 3: Las cantantes Juanita Manso (izquierda) y Julia Fons (derecha): fotografía tomada de la revista Mundo Gráfico, correspondiente al 12 de marzo de 1913, año III, $\mathrm{n}^{\circ} 72$.

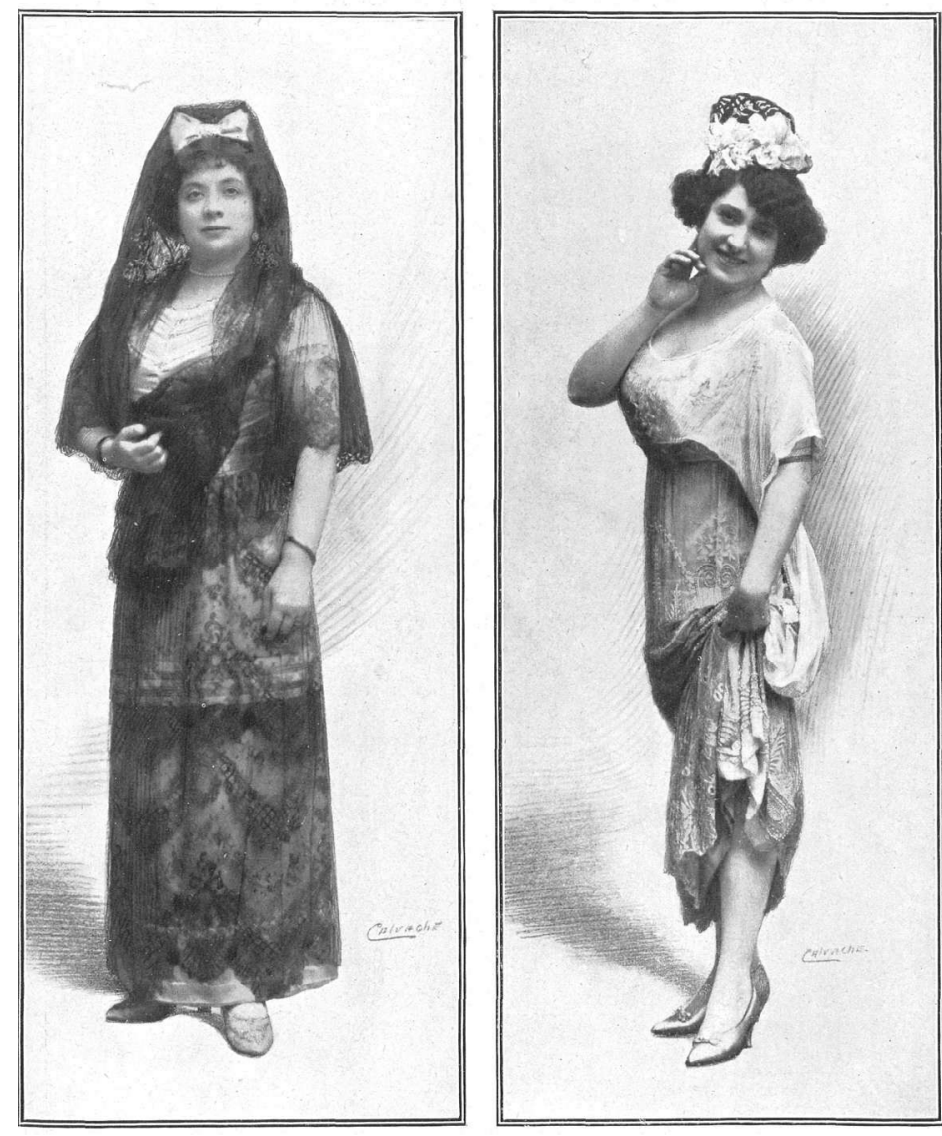

Fuente: Biblioteca Nacional de España. Madrid

En cuanto a los rasgos generales de las composiciones musicales de Vicente Lleó propias del género sicalíptico cabe mencionar los siguientes:

- Son piezas breves en un solo acto y escasos números musicales. No suelen sobrepasar de diez

- La revista, los sainetes, las zarzuelas y las operetas son los géneros musicales a las que Lleó recurre con mayor asiduidad

- Abundancia y variedad de esquemas formales en sus composiciones: cuplés, valses, chotis, garrotín

- Abuso del cuplé como forma musical en todo tipo de género musical: revistas, sainetes, zarzuelas, operetas, humoradas 
La obra sicalíptica de Vicente Lleó durante su etapa en el teatro eslava de Madrid (1907-1912) José Salvador Blasco Magraner • Pablo Marín-Liébana • Francisco Carlos Bueno Camejo

- Los números musicales como los cuplés añaden especias confiriendo un tono picante y subido de tono

- La melodía "insinuante", ligera, alegre y de fácil recuerdo es el elemento musical más significativo

- La tipología vocal preferida es la de soprano en las mujeres y la de tenor y barítono en los hombres

- Preferencia por los modos mayores, confiriendo una mayor luminosidad a la escena

- Las tonalidades presentan pocas alteraciones en la armadura, facilitando así la interpretación de la pieza

- Los conjuntos orquestales son, en general, más reducidos que los empleados en las representaciones de ópera

- La orquesta participa de forma más activa que en las piezas propias del género chico, subrayando en todo momento la acción escénica

- Profundo conocimiento de la orquestación en la que destaca la variedad y riqueza tímbrica

Podemos dividir la producción sicalíptica de Vicente Lleó en dos periodos bien diferenciados. El primero de ellos comprende los años 1906 hasta 1909 en los que el maestro valenciano muestra su preferencia por la composición de piezas menores propias del género chico como el sainete, la humorada, la fantasía, el pasatiempo, el cuento o el entremés. De este periodo destacan sus obras Venus Kursaal, La alegre trompetería y La carne flaca. Todas ellas poseen en común partituras con escasos números musicales en los que intervienen pocos personajes. Por ello es frecuente la alternancia de formas menores como arias, dúos y tercetos. La música se limita a servir al libreto y a resaltar lo que acontece en escena. Asimismo, el cuplé es el tipo de canción más utilizado. En este sentido, hay que tener en cuenta que en la primera década del siglo XX el cuplé se convirtió en la manifestación más característica de la canción popular española y, por tanto, en el género musical más conocido. Se trataba de una canción breve y picante interpretada por una mujer acompañada del baile, el canto y la teatralización. El interés del público residía, no tanto en 
La obra sicalíptica de Vicente Lleó durante su etapa en el teatro eslava de Madrid (1907-1912) José Salvador Blasco Magraner • Pablo Marín-Liébana • Francisco Carlos Bueno Camejo

la calidad de la interpretación, sino en la gracia y la picardía de la cupletista (ARREDONDO, 2014). El cuplé era un género urbano en el que cabía cualquier cosa, desde los ritmos de danza habituales en los espectáculos de zarzuela como el chotis y el vals, hasta los ritmos exóticos de moda como el tango, la guajira o el fox-trot (ALONSO, 1998). La "Canción de la regadera" incluida en La alegre trompetería, "La vendedora de besos" de la zarzuela La república del amor y los "cuplés babilónicos" de La corte de faraón, entre los que destaca la canción llena de sensualidad interpretada por Sul “iAy, ba!", son probablemente los cuplés de Vicente Lleó que más se popularizaron.

Figura 4. Imagen de un extracto de la partitura de La corte de faraón que contiene el tema principal de los cuplés de “iAy, babilonio!" en la que también aparece la cantante Carmen Andrés, en su papel de Sul y Vicente Lleó. Fotografía tomada de la revista Comedias y Comediantes correspondiente al 8 de febrero de 1910.

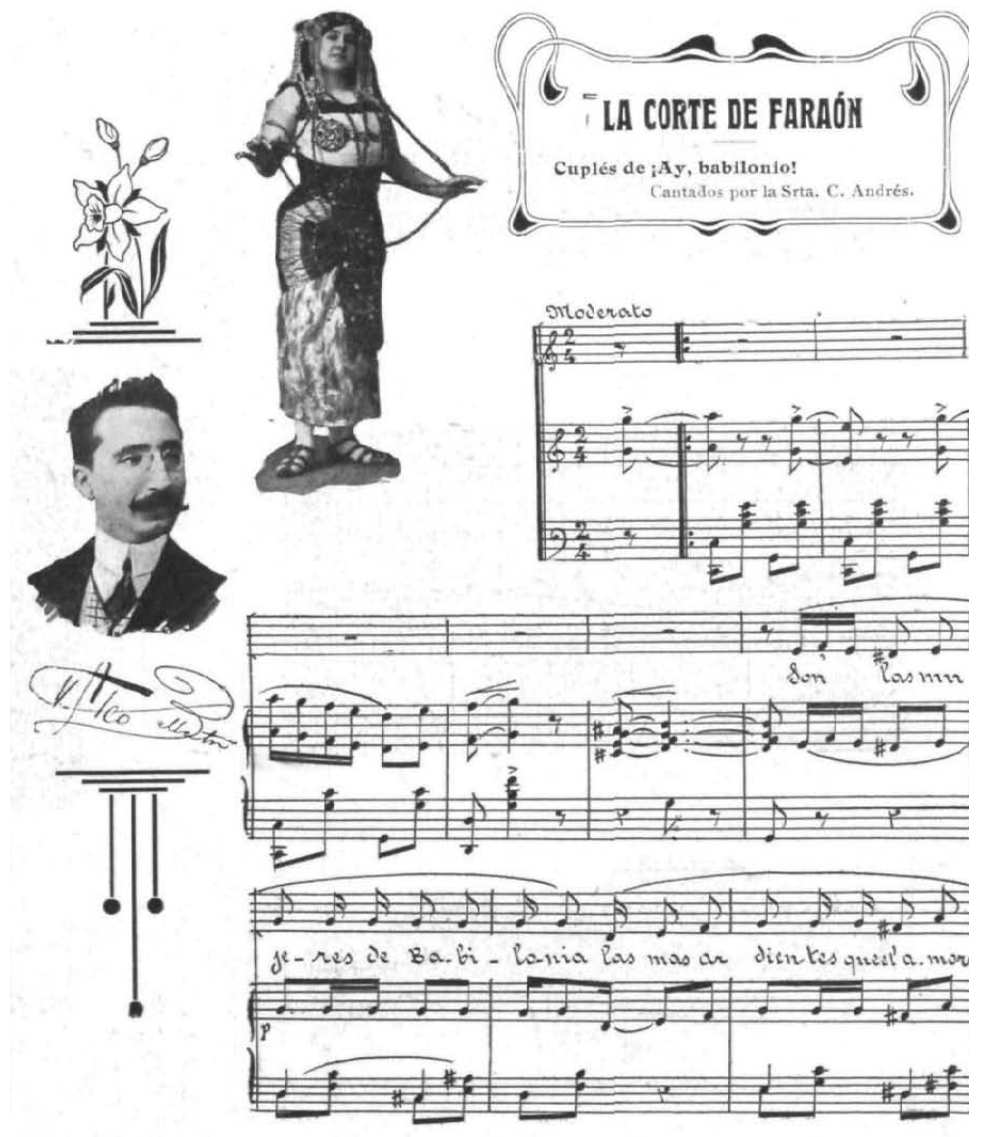


La obra sicalíptica de Vicente Lleó durante su etapa en el teatro eslava de Madrid (1907-1912) José Salvador Blasco Magraner • Pablo Marín-Liébana • Francisco Carlos Bueno Camejo

En este primer periodo compositivo Lleó recurre sobre todo a las tipologías vocales de tiple ligera y tiple cómica, modalidades vocales propias del género chico. Ha menester agregar que en aquella época se diferenciaba entre "tiple cantante", que se corresponde con la de voz tiple ligera de la actualidad, y "tiple cómica", que interpretaba un papel más provocativo, divertido y, en ocasiones grotesco y vulgar. Juanita Manso fue un ejemplo de tiple cantante, mientras que Julia Fons y Carmen Andrés fueron las tiples cómicas que más actuaron bajo la dirección de Vicente Lleó. Por su parte, la voz de tenor y de barítono fueron las más frecuentes entre las tipologías vocales masculinas. Los tenores cómicos José Gamero, quien alternó la zarzuela grande con el género chico, y Miguel Miró son los que más tardes de éxito compartieron con el maestro valenciano. Por su parte, en la voz de barítono es de destacar el cantante de origen aristocrático Carlos Allen-Perkin.

En cuanto a los conjuntos orquestales que Lleó dispone en sus obras no suelen sobrepasar los 40 miembros, siendo muy variable el número de músicos, así como los cambios frecuentes de instrumentación en sus partituras. No obstante, el conjunto sinfónico suele seguir el siguiente esquema que obedece a la formación orquestal prototípica del momento: 1-2 flautas, 1-2 oboes, 2 clarinetes y 2 fagots en las maderas; 2 cornetines, 2 trompas y 2-3 trombones en los metales; violines 1 , violines 2 , violas, violonchelos y contrabajos en las cuerdas; y, por último, caja, triángulo y timbal en la percusión. De la orquestación llama la atención que los violonchelos y los bajos tengan papeles claramente diferenciados en la mayoría de ocasiones, faceta ésta propia de los grandes orquestadores del siglo XIX. En cambio, apenas desarrolló la percusión limitándola a un número reducido de instrumentos.

A partir de 1909 se aprecia un cambio en la tendencia compositiva de Vicente Lleó dentro y fuera del género sicalíptico. De forma progresiva el maestro valenciano va abandonando algunas formas menores como fantasías, entremeses, humoradas y pasatiempos, mientras que la opereta se convierte en el género 
La obra sicalíptica de Vicente Lleó durante su etapa en el teatro eslava de Madrid (1907-1912) José Salvador Blasco Magraner • Pablo Marín-Liébana • Francisco Carlos Bueno Camejo

más frecuentado de su catálogo, seguido de la zarzuela. De este segundo periodo compositivo de Lleó destacan las zarzuelas EI método Gorritz y La moral en peligro, y la opereta La corte de faraón.

En esta segunda fase artística de Lleó se produce un aumento de los números musicales en sus composiciones. Este hecho se relaciona con el cambio de preferencia en los géneros musicales que el maestro cultivó. Así, por ejemplo, la partitura de la opereta La corte de faraón consta de 13 números musicales, más las tres introducciones y un intermedio que interpreta solo la orquesta. No obstante, este hecho no se puede generalizar a todas sus obras. EnEI método Gorritz Lleó escribió únicamente cinco números musicales. Además, en este periodo el músico valenciano se sirve con más asiduidad de coros fastuosos y números en los que intervienen todos los cantantes, al tiempo que dota a la partitura de una rica instrumentación con piezas de amplio conjunto orquestal. En este sentido, podemos hallar numerosos ejemplos en la zarzuela $L a$ moral en peligro, la opereta La corte de faraón y el sainete La maja de los claveles.

Asimismo, en esta segunda etapa se hace patente en la obra de Lleó la influencia de la opereta francesa y vienesa y de la ópera cómica francesa. Así, por ejemplo, en los "cuplés del miedo" de su zarzuela cómica La moral en peligro el músico valenciano parodia el célebre tema de la Habanera de la ópera Carmen de Bizet. 
La obra sicalíptica de Vicente Lleó durante su etapa en el teatro eslava de Madrid (1907-1912) José Salvador Blasco Magraner • Pablo Marín-Liébana • Francisco Carlos Bueno Camejo

Figura 5. Partitura de los "cuplés del miedo" de la zarzuela cómica La moral en peligro. En ella se puede apreciar la parodia del famoso tema de la Habanera de la ópera Carmen de Bizet Revista Comedias y Comediantes, 1 de noviembre de 1909.

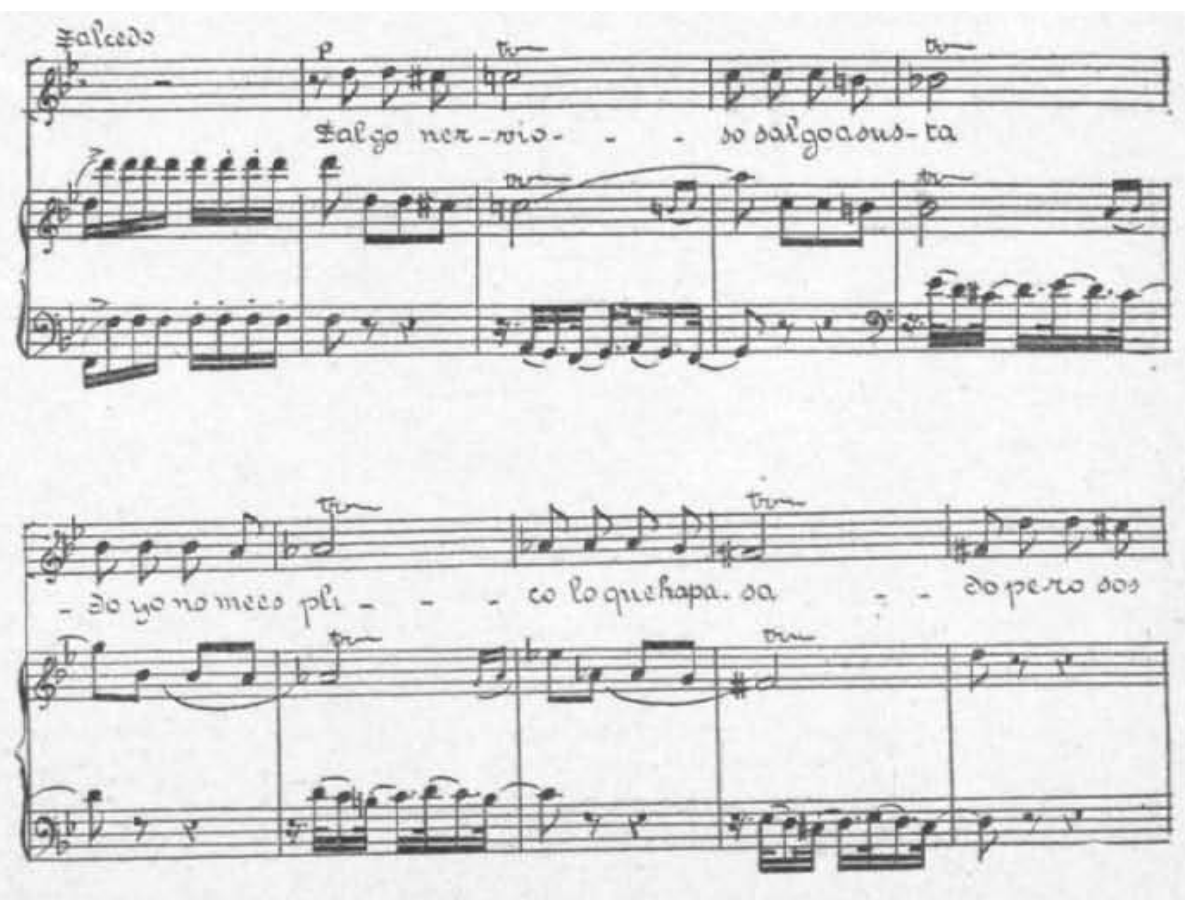

Fuente: Biblioteca Nacional de España. Madrid

En cuanto a las tipologías vocales hay que señalar el esfuerzo del compositor valenciano en su búsqueda para encontrar voces de calidad y renovar la escena. En este sentido, Lleó se trajo de Valencia al joven actor valenciano Ramón Peña y lo contrató como primer actor del Teatro Eslava. Peña se convirtió en el tenor cómico más querido por el público madrileño asiduo a las representaciones del género chico por su agudeza y gracia.

En este segundo periodo la orquesta de Lleó sufre una amplia transformación, aumentando el número de músicos que llegan a superar los 50 miembros. Todo un hito si tenemos en cuenta que los conjuntos orquestales de la época que actuaban en los teatros especializados en zarzuela y género chico eran bastante más reducidos que los de ópera. Así, por ejemplo, en la partitura de La corte de faraón Lleó aumenta considerablemente la familia de viento-metal y la de percusión, al tiempo que introduce 
La obra sicalíptica de Vicente Lleó durante su etapa en el teatro eslava de Madrid (1907-1912) José Salvador Blasco Magraner • Pablo Marín-Liébana • Francisco Carlos Bueno Camejo

instrumentos inusuales en las piezas propias del género chico como el arpa. La plantilla instrumental queda fijada de la siguiente disposición: flautín, 2 flautas, 2 oboes, 2 clarinetes en Si b, 2 fagots, 2 trompas en Fa, 3 trompetas en Do, 2 trompetas en Fa, 3 trombones, tuba, timbales, bombo, caja, lira, tam-tam, triángulo, arpa, violines I, violines II, violas, violonchelos y contrabajos.

\section{Su obra cumbre: La corte de faraón}

A finales de la primera década del siglo XX la opereta hacía furor en toda Europa. Se trataba de una modalidad teatral lírica, sentimental y sin grandes ni profundos asuntos que resolver (DOUGUERTY Y VILCHES, 1990). Así, por ejemplo, Vicente Lleó se inspiró en la opereta francesa, y más concretamente en la figura de Offenbach para componer la partitura de su obra cumbre: $L a$ corte de faraón (VILLORA, 2007).

La opereta bíblica La corte de faraón, basada en un libreto de Guillermo Perrín y Antonio Palacios fue estrenada el 21 de enero de 1910 en el Teatro Eslava. El argumento estaba basado en un episodio del Antiguo Testamento referido al casto José y a la mujer de Putifar. En esta obra se puede observar la presencia de características de la opereta, de la gran revista, del ballet parisiense y del género chico. Según Barrera en La corte de faraón la revista sicalíptica ha sido sustituida por una más fina pícara insinuación, unida a un rasgo muy característico de la opereta francesa: la cómica ridiculización de figuras legendarias, como José, Putifar y el faraón y de óperas de gran boato como Aida (BARRERA, 1992). En este sentido, el título del primer cuadro "¡Ritorna vincitor!" es una parodia de la ópera de Verdi, no en vano está escrita en italiano. De la gran revista La corte de faraón toma las frecuentes alusiones y críticas políticas a personalidades de la época como José Canalejas y Antonio Maura que aparecen incluso en los cuplés " ¡Ay, ba! y el "Vals del cangrejo". Asimismo, se observa la influencia del género chico en el uso de formas como el cuplé u otro tipo de 
La obra sicalíptica de Vicente Lleó durante su etapa en el teatro eslava de Madrid (1907-1912) José Salvador Blasco Magraner • Pablo Marín-Liébana • Francisco Carlos Bueno Camejo

danzas, como el "vals de las viudas" y el "aire español" del garrotín para unir lo que era propio de la opereta francesa con una música de raíz popular española. Todo ello, además, reforzado por una magnífica orquestación.

Zurita no duda en afirmar que La corte de faraón es la opereta cumbre de la música española, tanto por la calidad del libreto como por la excelsa partitura, prodigio de frivolidad y donosura (ZURITA, 1920). Por su parte, Alejandro Saint-Aubin, crítico de "El Heraldo de Madrid", aseveraba sobre la exitosa opereta que sentaría las bases por las que habría de discurrir la opereta cómica española:

Hablemos de la partitura y no vacilemos en calificarla de obra trascendental. ¿Diremos que puede ser considerada cual un Aida del género chico? Bueno, vaya por Aida, y evítense las discusiones. Pero por si alguno, tercamente, se empeña en entablar polémicas musicales, haremos la concesión de que sólo tiene alcance en el sentido de dar un sólido paso por el camino de la opereta cómica española (AUBIN, 1910, p. 3). 
La obra sicalíptica de Vicente Lleó durante su etapa en el teatro eslava de Madrid (1907-1912) José Salvador Blasco Magraner • Pablo Marín-Liébana • Francisco Carlos Bueno Camejo

Figura 6: Fotografía de Vicente Lleó Balbastre tomada de la revista Comedias y Comediantes correspondiente al 8 de febrero de 1910.

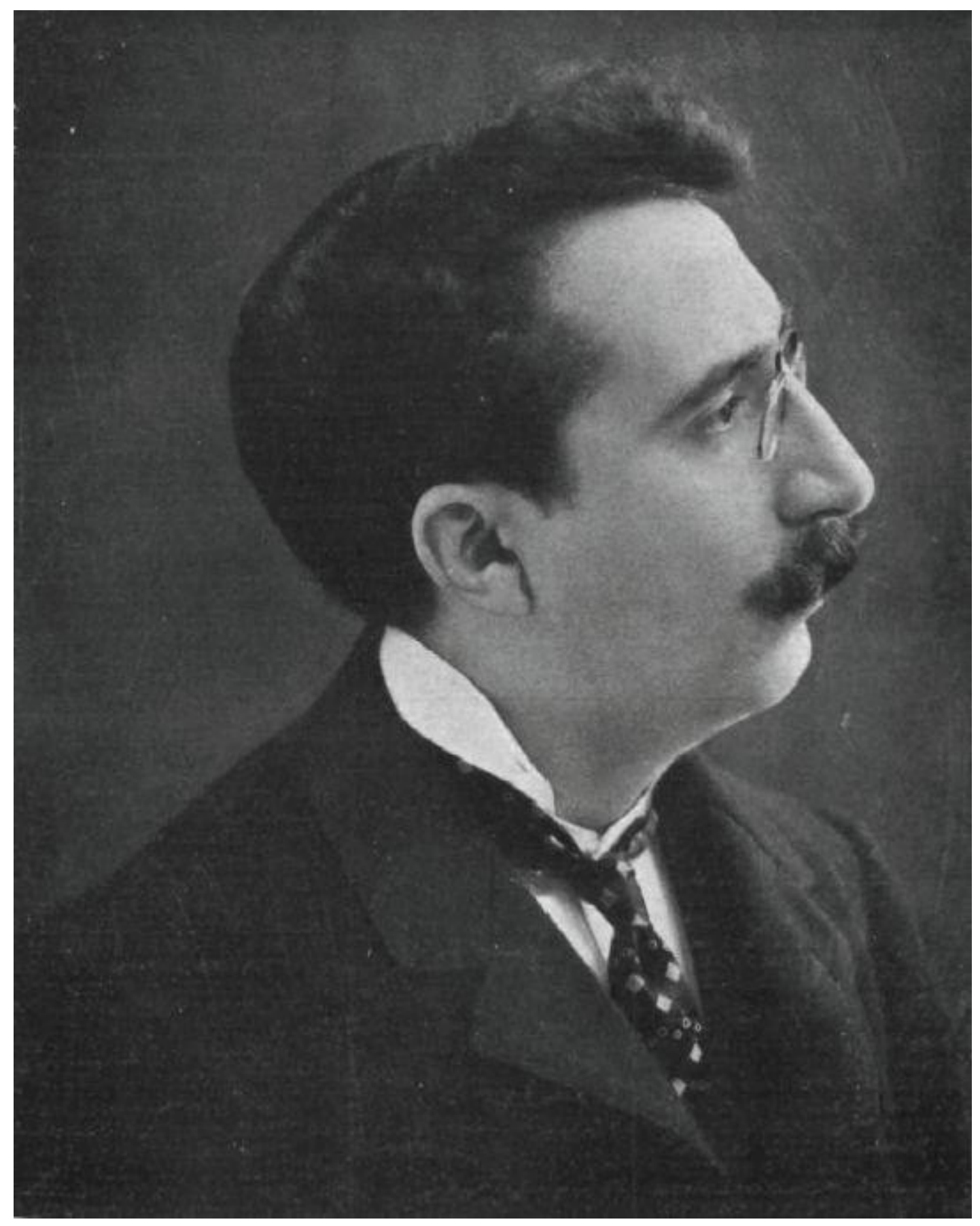

Fuente: Biblioteca Nacional de España. Madrid 
La obra sicalíptica de Vicente Lleó durante su etapa en el teatro eslava de Madrid (1907-1912) José Salvador Blasco Magraner • Pablo Marín-Liébana • Francisco Carlos Bueno Camejo

\section{Conclusiones}

A partir de 1900 se produjo una irrupción del erotismo escénico, de la canción de variedades y del cine que contaminaron al género chico desde dentro. Esta nueva modalidad teatral acuñó el nombre de género sicalíptico. El teatro sicalíptico se convirtió en el medio ideal para paliar los delirios eróticos y el lugar consentido para poder contemplarlos sin que escandalizase a aquella hipócrita sociedad española al comienzo del siglo XX. Temas de relevancia como la sexualidad, la castidad o la infidelidad fueron presentados de forma intranscendental en los proscenios de los teatros que representaban obras sicalípticas. Las clases medias y populares dieron rienda suelta a sus instintos sexuales más primarios y a la crítica sociopolítica más exacerbada. Tampoco faltaron la crítica y las veladas alusiones a personajes políticos como José Canalejas, Segismundo Moret y Antonio Maura, Presidentes todos ellos del Consejo de Ministros de España durante la regencia del monarca Alfonso XIII, cuya censura, aún actuando con frecuencia, no supo ver o permitió ciertas concesiones. Todo ello tuvo su origen en las dos tendencias ideológicas y políticas que acontecieron en Madrid durante las dos primeras décadas del siglo XX: una monárquica, cínica, cuya base social era la burocracia y el funcionariado, y otra humilde y de naturaleza rebelde formada por las clases trabajadoras y desocupados. El género sicalíptico perdurará en su apogeo en los escenarios hasta la década de los años veinte debido a la afición de Primo de Rivera por este tipo de espectáculos.

En este artículo se han recopilado y analizado todas las obras sicalípticas de Vicente Lleó Balbastre durante los años 1907 hasta 1912, etapa dorada de la sicalipsis en el teatro musical. Se puede afirmar que Vicente Lleó fue el máximo exponente y principal mantenedor del género sicalíptico durante el sexenio que estuvo al frente del Teatro Eslava de Madrid, componiendo la nada desdeñable cantidad de 35 obras dedicadas a este género. Durante este periodo de tiempo el coliseo del Pasadizo de San 
La obra sicalíptica de Vicente Lleó durante su etapa en el teatro eslava de Madrid (1907-1912) José Salvador Blasco Magraner • Pablo Marín-Liébana • Francisco Carlos Bueno Camejo

Ginés se convirtió en el templo de la sicalipsis. En el teatro Eslava tuvo lugar el estreno de algunos de los títulos más importantes del género sicalíptico como La corte de faraón. Sirviéndose al principio de un estilo más atrevido y procaz, Lleó supo evolucionar desde las formas menores propias del género chico hasta géneros mayores como la zarzuela y la opereta, esta última de clara influencia francesa y vienesa. A partir de 1909, la influencia de la opereta europea fructificó en un nuevo género sicalíptico de insinuación más fina dotado de una crítica política más contenida. Todo ello sin abandonar las características propias del género chico y la música de raíz popular española. Mientras la calidad de los libretos de sus obras se mantenían fieles a los postulados del género chico, el maestro valenciano amplió los límites provincianos a los que se hallaban sometidos los compositores españoles de la época que cultivaban el género chico, imitando los rasgos característicos de la opereta francesa. De esta manera, comenzaron a prodigar en las partituras del maestro valenciano números grandiosos en los que intervenían todos los cantantes; piezas de amplio conjunto orquestal, -conseguidas a través de un aumento considerable del número de músicos que, en ocasiones, superaba con creces la cantidad habitual de intérpretes que actuaban en el foso de las compañías de zarzuela-; que recordaban algunas de las más brillantes composiciones de los más grandes maestros. Todo ello alternado con formas menores como dúos o tercetos, así como una vuelta a las raíces del género, realizando concesiones al gusto popular de la asistencia en forma de cuplés u otro tipo de danzas como los valses, los chotis y los alegres garrotines. Todo ello produjo la dignificación del género sicalíptico y preparó el camino por el que habría de discurrir la opereta cómica española.

\section{Referencias}

ALIER, Roger. La zarzuela. Barcelona: Ma Non Troppo, Ediciones Robinbook. 
La obra sicalíptica de Vicente Lleó durante su etapa en el teatro eslava de Madrid (1907-1912) José Salvador Blasco Magraner • Pablo Marín-Liébana • Francisco Carlos Bueno Camejo

ALONSO, Celsa. "Juan Martínez Abades: marinista cupletero o cupletista pintor". En: Xose Aviñoa (Ed.), Miscel. Lania Oriol Martorell, Universitat de Barcelona, 1998.

ARESTI, Nerea. "Ideales y expectativas: la evolución de las relaciones de género en el primer tercio del siglo XX". Gerónimo de Uztariz, 21, 2005, p, 67-80.

ARREDONDO PÉREZ, Herminia. “Antecedentes de la canción teatral a la canción española: la mujer espectáculo". En Francisco José García Gallardo y Herminia Arredondo Pérez (Ed.), Andalucía en la música. Sevilla: Fundación Pública Andaluza, 2014.

AUBIN, Alejandro. "La corte de faraón". En: El Heraldo de Madrid, 23 de enero de 1910.

BALLARÍN DOMINGO, Pilar. La educación de la mujer española en el siglo XIX. Revista interuniversitaria de historia de la educación, 8. 1989, p, 245-260.

BARRERA, Antonio. Crónicas del género chico y de un Madrid divertido. Madrid: Editorial El Avapiés, 1992.

BLASCO MAGRANER, José Salvador. Los inicios del erotismo en la escena teatral lírica madrileña, La Laguna: Cuadernos de Bellas Artes, 2014.

COMEDIAS Y COMEDIANTES, 8 de febrero de 1910.

COMEDIAS Y COMEDIANTES, 1 de noviembre de 1909.

DOUGUERTY, Dru y VILCHES, María Francisca. La escena madrileña entre 1918 y 1926: Análisis y documentación, Madrid: Editorial Fundamentos, 1990.

EL HERALDO DE MADRID, 17 de marzo de 1907.

EL HERALDO DE MADRID, 28 de marzo de 1909.

EL PAÍS, 28 de marzo de 1909.

EL PAÍs, 20 de octubre de 1910. 
La obra sicalíptica de Vicente Lleó durante su etapa en el teatro eslava de Madrid (1907-1912) José Salvador Blasco Magraner • Pablo Marín-Liébana • Francisco Carlos Bueno Camejo

GALBIS, Vicente. "Lleó Balbastre, Vicente”, En Diccionario de la Música Valenciana, dirigido por Emilio Casares Rodicio, Madrid: Iberautor Pomociones Culturales, vol. II, 2006.

ÍNIGUEZ-BARRENA, Francisca. La parodia teatral en España (18681914). Sevilla: Universidad de Sevilla

KIRKPATRICK, Susan. Mujer, modernismo y vanguardia en España (1898-1931). Madrid: Ediciones Cátedra. Universitat de València, 2003. LABRADOR BEN, Julia María. Teatro frívolo y teatro selecto. Madrid: Editorial CSIC-CSIC PRESS, 2005.

LA CORRESPONDENCIA DE ESPAÑA, 20 de octubre de 1910. LEAL, Juan Felipe. El cinematógrafo y los teatros. Anales del cine en México, 1895-1911, vol. 6, México: Editorial Voyeur, 2009. MONTIJANO RUIZ, Juan José. Historia del teatro olvidado: la revista (1864-2009), Tesis Doctoral, Universidad de Granada, 2009.

MUNDO GRÁFICO, Año III, nº 72, 12 de marzo de 1913.

MUÑOZ LORENTE, Gerardo. Glosario panhispánico del amor y el sexo, Madrid: Ediciones de La Torre, 2008.

OLIVA, César, Teatro y sociedad en la España del siglo XX. En: Fidel López Criado (Coord.), Literatura y sociedad, el papel de la literatura en el siglo XX. Universidade da Coruña, 2000.

OZIEBLO, Bárbara. “Una imagen propia: la innovación protagonizada por dramaturgas norteamericanas de principios de siglo". En: Rosa García y Eulalia Piñero (Ed.), Voces e imágenes de mujeres en el teatro del siglo XX. Madrid: Universidad Complutense, 2002.

PETSCHEN VERDAGUER, Santiago. “España y el Vaticano del Concordato de 1851 a 1953", En: Paul Aubert (Ed.), Religión y sociedad en España siglos XIX y XX, Madrid, Editorial Casa de Velázquez, 2002.

RIVAS, Enrique. “El público sicalíptico”, En: El Heraldo de Madrid, 17 de noviembre de 1906.

SALAÜN, Serge. "El teatro español en la encrucijada", En Literatura modernista y tiempo del 98, Universidad de Santiago de Compostela, 2000. 
La obra sicalíptica de Vicente Lleó durante su etapa en el teatro eslava de Madrid (1907-1912) José Salvador Blasco Magraner • Pablo Marín-Liébana • Francisco Carlos Bueno Camejo

SÁNCHEZ MARROYO, Fernando. La España del siglo XX. Economía, demografía y sociedad. Madrid: Colección Fundamentos, 2003.

VILCHES, Lorenzo. Diccionario de teorías narrativas: cine, televisión, transmedia. Madrid: Caligrama Editorial.

VÍLLORA, Pedro. Teatro frívolo. Madrid: Editorial Fundamentos, 2007. ZURITA, Marciano. Historia del género chico, Madrid: Prensa Popular, 1920. 